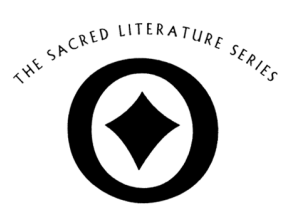

\title{
THE SPIRIT OF THE BUDDHA
}





\section{THE SPIRIT OF THE BUDDHA}

MARTINE BATCHELOR

PUBLISHED IN ASSOCIATION WITH

THE INTERNATIONAL SACRED LITERATURE TRUST

YALE UNIVERSITY PRESS

NEW HAVEN LONDON 
Copyright (C) 2010 by Martine Batchelor

All rights reserved. This book may not be reproduced in whole or in part, in any form (beyond that copying permitted by Sections 107 and 108 of the U.S, Copyright Law and except by reviewers for the public press), without written permission from the publishers.

For information about the Sacred Literature Series and other Yale University Press publications please contact:

U.S. Office: sales.press@yale.edu_yalebooks.com

Europe Office: sales@yaleup.co.uk_www.yalebooks.co.uk

Set in Arno Pro by IDSUK (DataConnection) Ltd

Printed in Britain by Hobbs the Printers Ltd, Totton, Hampshire

Library of Congress Cataloging-in-Publication Data

Batchelor, Martine.

The spirit of the Buddha / Martine Batchelor.

p. cm.

Published in association with the International Sacred Literature Trust.

Includes bibliographical references.

ISBN 978-0-300-16407-7

1. Gautama Buddha-Teachings. 2. Buddhism-Doctrines. I. Tipitaka.

English. Selections. II. Title.

BQ1172.E5B38 2010

$294.3^{\prime} 82-\mathrm{dc} 22$

2010016209

A catalogue record for this book is available from the British Library.

$\begin{array}{llllllllll}10 & 9 & 8 & 7 & 6 & 5 & 4 & 3 & 2 & 1\end{array}$ 


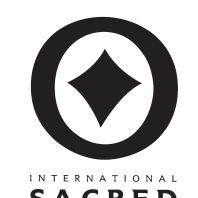

SACRED

LITERATURE

The International Sacred Literature Trust was established to promote understanding and open discussion between and within faiths and to give voice in today's world to the wisdom that speaks across time and traditions.

What resources do the sacred traditions of the world possess to respond to the great global threats of poverty, war, ecological disaster, and spiritual despair?

Our starting-point is the sacred texts with their vision of a higher truth and their deep insights into the nature of humanity and the universe we inhabit. The publishing program is planned so that each faith community articulates its own teachings with the intention of enhancing its self-understanding as well as the understanding of those of other faiths and those of no faith.

The Trust especially encourages faiths to make available texts which are needed in translation for their own communities and also texts which are little known outside a particular tradition but which have the power to inspire, console, enlighten, and transform. These sources from the past become resources for the present and future when we make inspired use of them to guide us in shaping the contemporary world.

Our religious traditions are diverse but, as with the natural environment, we are discovering the global interdependence of human hearts and minds. The Trust invites all to participate in the modern experience of interfaith encounter and exchange which marks a new phase in the quest to discover our full humanity. 

To the memorists, scholars and translators of ancient and present times 
